\title{
ISOLATION AND PURIFICATION OF CUCURBITACIN D AND I FROM ECBALLIUM ELATERIUM (L.) A. RICH FRUIT JUICE
}

\author{
Emir Tosun, Ahmet Baysar* \\ Department of Chemical Engineering, Faculty of Engineering, İnönü University, \\ 44280 Battalgazi, Malatya, Turkey \\ ahmet.baysar@inonu.edu.tr
}

\begin{abstract}
The objective of this study was to develop a rapid, economic, and efficient method for simultaneous selective isolation, separation, and purification of cucurbitacin D and I from Ecballium elaterium (L.) A. Rich fruit juice via reversed-phase flash chromatography combined with HPLC. The chloroform extract of the fruit juice was fractionated with flash chromatography using a chloroform, acetone and methanol solvent combination at a $5 \mathrm{ml} / \mathrm{min}$ flow rate. Then, a validated HPLC method was utilized for purification of the two targeted cucurbitacins. Cucurbitacin D and I were collected automatically by the fraction collector. The fractions containing the same compounds were pooled and lyophilized. The purified cucurbitacin D and I compounds were identified by NMR, LC-MS, and UV spectra analysis. The results suggest that the applied procedure is simple, quick, and highly efficient. The HPLC method was found to be linear, accurate, precise and rugged for the quantification of the cucurbitacins studied.
\end{abstract}

Keywords: cucurbitacin D; cucurbitacin I; Ecballium elaterium (L.) A. Rich; isolation; method validation

\section{ИЗОЛАЦИЈА И ПРЕЧИСТУВАЊЕ НА КУКУРБИТАЦИН D И І ОД ОВОШЕН СОК HA ECBALLIUM ELATERIUM (L.) A. RICH}

Целта на ова истражување беше да се развие брз, економичен и ефикасен метод за истовремено селективно изолирање, раздвојување и пречистување на кукурбитацин D и I од овошен сок на Ecballium elaterium (L.) A. Rich преку реверзно фазна флеш-хроматографија комбинирана со HPLC. Хлороформскиот екстракт беше фракциниран со флеш-хроматографија со употреба на раствор со комбинација од хлороформ, ацетон и метанол со брзина на проток од 5 $\mathrm{ml} / \mathrm{min}$. Потоа беше применет валидиран HPLC метод за пречистување на двата целни кукурбитацини. Кукурбитацини D и I беа автоматски собрани со фракционен колектор. Фракциите што ги содржеа истите соединенија беа обединети и лиофилизирани. Пречистените кукурбитацини D и I беа идентификувани по пат на NMR, LC-MS, и UV спектрална анализа. Беше утврдено дека со методот HPLC е линеарен, точен, прецизен и робустен за квантификација на испитуваните кукурбитацини.

Клучни зборови: кукурбитацин D; кукурбитацин I; Ecballium elaterium (L.) A. Rich; изолација; валидација на метод

\section{INTRODUCTION}

Ecballium elaterium (L.) A. Rich (E. elaterium), which grows naturally in the Mediterranean region, is known as the squirting cucumber $[1,2]$.
It has numerous biological activities in vitro such as analgesic, antipyretic, anti-hepatotoxic, anticancer, anti-inflammatory and cytotoxic [3-5]. The plant extract and the fruit juice have been widely 
used for long time as a folk medicine to specifically treat sinusitis $[6,7]$.

E. elaterium is a rich source of cucurbitacin type secondary metabolites. The cucurbitacins are a group of highly oxygenated tetracyclic triterpenes having a unique $19-(10 \rightarrow 9 \beta)$-abeo-10lanost-5-ene (cucurbitane) skeleton (Fig. 1).

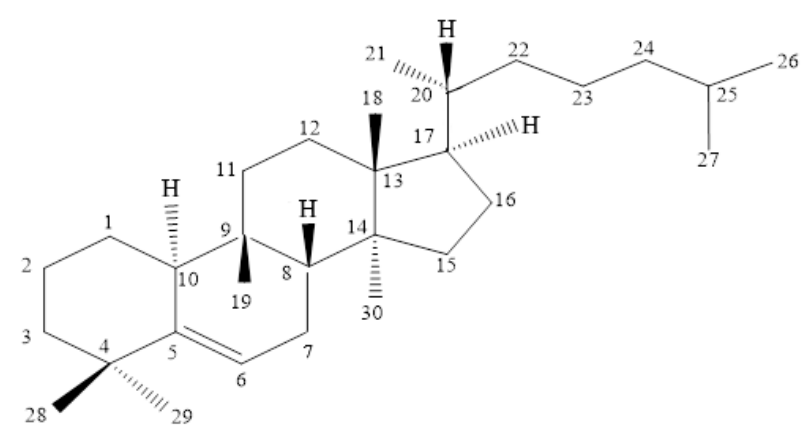

Fig. 1. General structure of cucurbitacins

Cucurbitacins are generally crystalline substances at room temperature. Most of them are slightly soluble in water but very soluble in petroleum ether, chloroform, benzene, ethyl acetate, methanol and ethanol. Their absorption maxima for ultraviolet light (UV) is between 228 and 234 $\mathrm{nm}$ depending on the type of cucurbitacin $\left[2,8_{-}\right.$ 10]. The cucurbitacins exhibit a wide range of biological activities in living beings. They have been investigated for their cytotoxic, hepatoprotective, anti-diabetic, anti-bacterial, anti-inflammatory, antimicrobial, cardiovascular, and antioxidant activities. Additionally, some cucurbitacin species inhibit the proliferation of cancer cells [5, 8-15]. Currently, 12 classes of cucurbitacins are known which contain 16 cucurbitacin types, and they are grouped according to the variations in their molecular structure $[8,15]$. Cucurbitacins B, E, D and I are the main cucurbitacins in the E. elaterium fruit [7]. Cucurbitacins B, D, E, I, L, R and their derivatives have been previously identified in E. elaterium fruit juice $[4,6]$.

Some studies report procedures for the extraction and isolation of cucurbitacins from different plants of Cucurbitaceae family [16-18]. The extraction of cucurbitacins is generally applied to the plant material or to the dried fruit juice using methanol or ethanol. Chloroform is mostly used for the purification of cucurbitacins from the alcoholic extracts because of their partition between water and chloroform $[9,19]$. To our knowledge, there is no study on the extraction of cucurbitacin $\mathrm{D}(\mathrm{Cu}$ D) and cucurbitacin I ( $\mathrm{Cu}$ I) directly with chloroform from the juice of the fruit. Isolation can also be accomplished with different chromatographic protocols such as column chromatography and TLC. TLC has been utilized for the purification of cucurbitacins from plant extracts [9, 15, 19-22]. However, these techniques are time and solvent consuming.

Different techniques such as Flash Chromatography (FC) and HPLC may be used for the isolation and purification of plant extracts. FC is a rapid and economical method for the separation of mixtures at relatively high flow rates. FC offers good separation and can be used in both normal phase and reverse phase separations, but to the best of our knowledge, the use of FC has barely been studied to separate cucurbitacin species [23, 24].

HPLC is a good instrument for separating individual cucurbitacins from mixtures [19]. The use of HPLC coupled to a diode-array (HPLCDAD) detector has undoubtedly made things much easier, allowing for quick and efficient characterization of crude extracts [9].

An HPLC method using gradient elution of Acetonitrile $(\mathrm{ACN})$ in water has been documented for the analysis of a number of the main cucurbitacin types commonly found in plants $[20,21,25-$ 28]. HPLC purification may be achieved by separating the target compound from the other compounds. For an optimum purification, each compound should give a characteristic peak under the chosen chromatographic conditions such as the proper mobile phase, flow rate, detector, and column type [29]. Table 1 summarizes different analytical and preparative methods for the analysis of cucurbitacins by HPLC in the literature.

The aim of the present study was to develop and validate a simple, rapid, economical, and efficient method to simultaneously isolate, separate, purify and identify $\mathrm{Cu} \mathrm{D}$ and $\mathrm{Cu} \mathrm{I}$ from E. elaterium fruit juice with high yield. 
Analytical and preparative methods for the analysis of cucurbitacins by HPLC

\begin{tabular}{|c|c|c|c|c|c|c|}
\hline $\begin{array}{l}\text { Stationary phase } \\
\text { (Column) }\end{array}$ & Mobile phase & $\begin{array}{l}\text { Flow rate } \\
(\mathrm{mL} / \mathrm{min})\end{array}$ & $\begin{array}{l}\text { Elution type and } \\
\text { program }\end{array}$ & $\begin{array}{l}\begin{array}{l}\text { Determined } \\
\text { cucurbitacin }\end{array} \\
\end{array}$ & $\begin{array}{c}\text { Wavelenght } \\
(\mathbf{n m})\end{array}$ & Reference \\
\hline $\begin{array}{l}\text { (A) Analytical; Nucle- } \\
\text { osil } 100-5 \mathrm{C} 18(250 \\
\mathrm{mm} \times 4 \mathrm{~mm} \text { i.d; } 5 \mu \mathrm{m}) \\
\text { protected by a precol- } \\
\text { umn } \\
\text { (B) Semipreparative; } \\
\text { C18 }(250 \mathrm{~mm} \times 10 \mathrm{~mm} \\
\text { i.d; } 5 \mu \mathrm{m})\end{array}$ & $\begin{array}{l}\text { (A) } \mathrm{A}: \mathrm{H}_{2} \mathrm{O}: \text { formic } \\
\text { acid }(99.5: 0.5) \\
\mathrm{B}: \text { Methanol: acetoni- } \\
\text { trile }(50: 50) \\
\text { (B) } \mathrm{A}: \mathrm{H}_{2} \mathrm{O}: \text { formic } \\
\text { acid }(99.5: 0.5) \\
\mathrm{B}: \text { Methanol: acetoni- } \\
\text { trile }(50: 50)\end{array}$ & $\begin{array}{l}\text { (A) } 0.8 \\
\text { (B) } 2\end{array}$ & $\begin{array}{l}\text { (A) Gradient; } \\
\text { starting at } 10 \% \mathrm{~B}, 50 \% \mathrm{~B} \\
\text { at } 16 \mathrm{~min}, 80 \% \mathrm{~B} \text { at } 30 \\
\text { min, } 100 \% \mathrm{~B} \text { at } 33 \mathrm{~min} \text {, } \\
\mathrm{B} \text { was maintained at } \\
100 \% \text { for another } 2 \mathrm{~min} \text {. } \\
\text { (B) Isocratic }\end{array}$ & $\begin{array}{l}\text { Cucurbitacin B, D, E, I } \\
\text { and glycosides }\end{array}$ & 230 & [4] \\
\hline $\begin{array}{l}\text { (A) Preperative; } \\
\text { Econosil C18 } 250 \times 22 \\
\mathrm{~mm}, 10 \mu \mathrm{m} \\
\text { (B) Analytical; } \\
\text { Alltima C18 } 250 \times 4.6 \\
\text { mm i.d., } 5 \mu \mathrm{m}\end{array}$ & $\begin{array}{l}\text { (A) A: Acetonitrile, } \\
\text { B: Water or A: Meth- } \\
\text { anol, B: Water } \\
\text { (B) A: Acetonitrile, } \\
\text { B: Water or A: Meth- } \\
\text { anol, B: Water }\end{array}$ & $\begin{array}{l}\text { (A) } 13 \\
\text { (B) } 1\end{array}$ & $\begin{array}{l}\text { (A) Gradient; } \\
\text { Acetonitrile (20-55\% in } \\
50 \text { min.), or methanol } \\
\text { (60-75\% in } 50 \text { min.) } \\
\text { (B) Acetonitrile ( } 30-70 \% \\
\text { in } 57 \text { min.), and metha- } \\
\text { nol (60-75\% in } 50 \text { min.) }\end{array}$ & Cucurbitacins & unspecified & {$[20]$} \\
\hline $\begin{array}{l}\text { Eurospher } \mathrm{C}_{18} \\
(250 \mathrm{~mm} \times 4 \mathrm{~mm} \text { i.d; } 5 \\
\mu \mathrm{m})\end{array}$ & $\begin{array}{l}\text { A: Acetonitrile, } \\
\text { B: Water }\end{array}$ & 1 & $\begin{array}{l}\text { Gradient; 0-35 min } \\
\text { linearly from } 20 \% \text { A to } \\
60 \% \mathrm{~B}, 35-40 \mathrm{~min} \text { line- } \\
\text { arly from } 60 \% \text { to } 20 \% \text {, } \\
\text { then held for } 5 \mathrm{~min} \text {. }\end{array}$ & $\begin{array}{l}\text { Cucurbitacin E; } \\
\text { Cucurbitacin I; } \\
\text { Cucurbitacin E glycoside; } \\
\text { Cucurbitacin I glycoside }\end{array}$ & 230 & [26] \\
\hline $\begin{array}{l}\text { Hewlett Packard } \\
20 \mathrm{~cm} \times 4.6 \mathrm{~mm} \text { i.d., } \\
10 \mu \mathrm{m}\end{array}$ & $\begin{array}{l}\text { A: Acetonitrile-water } \\
(2: 8) \\
\text { B: Acetonitrile-water } \\
(45: 55)\end{array}$ & 2 & $\begin{array}{l}\text { Gradient, } \\
\text { starting } 100 \% \mathrm{~A}, \\
0 \% \mathrm{~A}(0-35 \mathrm{~min} .)\end{array}$ & $\begin{array}{l}\text { Cucurbitacin B, D, E, I, } \\
\text { 3-epi-iso-cucurbitacin D } \\
\text { and two glycosides }\end{array}$ & 229 & [27] \\
\hline $\begin{array}{l}\text { Kromasil C8 } \\
(150 \mathrm{~mm} \times 4.6 \mathrm{~mm} \mathrm{ID}, \\
5 \mu \mathrm{m})\end{array}$ & $\begin{array}{l}\text { Acetonitrile - } 2 \% \\
\text { Acetic acid }\end{array}$ & 1 & Linear gradient & $\begin{array}{l}23,24- \\
\text { dihydrocucurbitacin F;23, } \\
\text { 24- dihyrocucurbitacin D; } \\
\text { Cucurbitacin B; } \\
\text { Cucurbitacin E }\end{array}$ & 215 & {$[28]$} \\
\hline $\begin{array}{l}\text { (A) Analytical; Supel- } \\
\text { co®) } 150 \times 4.6 \mathrm{~mm}, 5 \\
\mu \mathrm{m} \\
\text { (B) Preperative; } \\
\text { Shimadzu }{ }^{\circledR}, \\
\text { ODS, PREP-ODS, } 20 \times \\
250 \mathrm{~mm}\end{array}$ & $\begin{array}{l}\text { (A) Acetonitrile- } \\
\text { Water (40:60) } \\
\text { (B) Acetonitrile- } \\
\text { Water (42:58) }\end{array}$ & $\begin{array}{l}\text { (A) } 1.2 \\
\text { (B) } 6\end{array}$ & Isocratic & $\begin{array}{l}\text { Dihydrocucurbitacin B; } \\
\text { Cucurbitacin B }\end{array}$ & 230 & [30] \\
\hline $\begin{array}{l}\text { TSK Gel ODs 120A } \\
150 \times 4.6 \mathrm{~mm}\end{array}$ & $\begin{array}{l}\text { Acetonitrile-water } \\
(2: 3)\end{array}$ & 1 & Isocratic & Cucurbitacin B & 230 & {$[31]$} \\
\hline $\begin{array}{l}\text { Bio-Sil C18 HL 90-5S; } \\
250 \times 4.6 \mathrm{~mm} \text { i.d., } 5 \\
\mu \mathrm{m}\end{array}$ & $\begin{array}{l}\text { A: Acetonitrile } \\
\text { B: Water }\end{array}$ & 2 & $\begin{array}{l}\text { Gradient; } \\
\text { starting 20\% A, } \\
45 \% \text { A (0-35 min.) }\end{array}$ & Cucurbitacin E & 229 & {$[32]$} \\
\hline $\begin{array}{l}\text { LiChrospher } 100 \mathrm{RP}- \\
18 \mathrm{e}(4 \mathrm{~mm} \text { i.d. } \times 250 \\
\mathrm{mm}, 5 \mu \mathrm{m}) \\
\text { Column temperature } \\
40^{\circ} \mathrm{C}\end{array}$ & $\begin{array}{l}0.05 \% \text { Trifluoroacetic } \\
\text { acid-methanol }(42: 58)\end{array}$ & 1 & Isocratic & $\begin{array}{l}\text { Cucurbitacin E; } \\
\text { Cucurbitacin I; } \\
\text { Cucurbitacin E glycoside; } \\
\text { Cucurbitacin I glycoside }\end{array}$ & 236 & [33] \\
\hline Analytical C18 & $\begin{array}{l}\text { A: Water, } \\
\text { B: Acetonitrile }\end{array}$ & 1 & $\begin{array}{l}\text { Gradient; starting with } \\
100 \% \text { of water and } \\
\text { minutes A } 80 \% \text {, B } 20 \% \text {, } \\
\text { after } 10 \text { min A } 60 \% \text {, } \\
\text { B } 40 \% \text { and after } 5 \text { min } \\
\text { A } 40 \%, \text { B } 60 \% \text {. }\end{array}$ & $\begin{array}{l}\text { Cucurbitacin E; } \\
\text { Cucurbitacin I }\end{array}$ & 229,254 & {$[34]$} \\
\hline
\end{tabular}

\section{MATERIALS AND METHODS}

\subsection{Materials, instruments, standards and reagents}

Ripe fruits of E. elaterium were collected in September from Adana province, Turkey and stored at $18^{\circ} \mathrm{C}$ until processed. The plant was identified by Dr. Turan Arabac1 (Faculty of Pharmacy, İnönü University). The voucher specimens were deposited in the Herbarium of İnönü University (INU), Malatya, Turkey.
A Nüve EV 018 vacuum oven (Nüve, Turkey), a Büchi Rotavapor R-210 (Büchi, Switzerland), and an Alpha 1-2/LD Plus freeze dryer (Martin Christ, Osterode Germany) were used for sample preparation.

The FC separation was performed on a Büchi (Switzerland) FC system with dual C-601 pump modules, C-615 pump manager, C-660 fraction collector, C-635 UV photometer, and silica gel filled (Merck, $70-230$ mesh) $21.0 \times 129 \mathrm{~mm}$ polypropylene cartridges.

A Shimadzu LC-20AD Prominence HPLC system (Shimadzu Corp., Kyoto, Japan) was used 
for purification/separation tests. It had a DAD detector (SPD-M20A) equipped with a pump system, an auto sampler (SIL-20A HT), a column heater (CTO-20A), a fraction collector (FRC-10A), and a degasser unit (DGU-20A5).

An Agilent 1100 LC/MSD SL single quadruple mass spectrometer (Agilent Technologies, Palo Alto, CA) was used for measuring ESI-MS. ${ }^{1} \mathrm{H}$ NMR spectra were recorded at $600 \mathrm{MHz}$ on a Bruker Avance III 600 spectrometer (Bruker, Rheinstetten, Germany).

$\mathrm{Cu} \mathrm{D}$ and $\mathrm{Cu}$ I standards (purity of $\geq 95 \%$ ) were purchased from Extrasynthese (Genay, France). HPLC grade solvents (acetone, ACN, chloroform, hexane and methanol) were obtained from Carlo Erba (Milan, Italy). All mobile phase solvents were ultrasonically degassed before use. Ultrapure water used for all experiments was produced by a Millipore Synergy UV purification system (Molsheim, France).

\subsection{Extraction and isolation of cucurbitacins}

The ripe fruits were pressed. The juice was collected and strained. The juice was filtered through a double layer cheesecloth, then through filter paper, and dried in the vacuum oven at $23{ }^{\circ} \mathrm{C}$. To prevent degradation of secondary metabolites, the residue was stored at about $-18^{\circ} \mathrm{C}$ prior to utilization for extraction.

Five grams of dried residue was dissolved in $50 \mathrm{ml}$ deionized water. This aqueous solution was extracted three times with $50 \mathrm{ml}$ hexane at $40^{\circ} \mathrm{C}$ for $6 \mathrm{~h}$ to remove waxes, pigments, high boiling terpenes, apolar fatty acids, and lipids. After extraction, the phases were separated and stored at $-18{ }^{\circ} \mathrm{C}$ until analysis.

The remaining aqueous phase $(49 \mathrm{ml})$ was extracted with chloroform $(50 \mathrm{ml})$, which has high affinity for cucurbitacins. The extraction with chloroform was performed three times at room temperature for $6 \mathrm{~h}$. The extract was then filtered and concentrated to $10 \mathrm{ml}$ by the rotary evaporator under reduced pressure at $40{ }^{\circ} \mathrm{C}$. This organic phase contained a mixture of partially purified cucurbitacins.

FC was used for the fractionation of the chloroform extract to obtain pure cucurbitacins in target fractions. The solvent system used for FC was chosen from TLC separation experiments. For this purpose, the optimum solvent system ratio giving the best separation of $\mathrm{Cu} \mathrm{D}$ and $\mathrm{Cu}$ I was determined from several solvent systems. Standards and test samples were spotted on TLC silica gel $60 \mathrm{~F}_{254}$ aluminum sheets (Merck, Darmstadt, Germany). The solvent system which gave the best separation was a chloroform-acetone-methanol $(77: 10: 13 ; \mathrm{v} / \mathrm{v} / \mathrm{v})$ solution. The $\mathrm{Rf}$ values for $\mathrm{Cu} \mathrm{D}$ and $\mathrm{Cu}$ I were found to be 0.61 and 0.69 , respectively.

The flash column was first equilibrated with chloroform, and then the chloroform extract (total of $10 \mathrm{ml}$ ) was eluted with isocratic elution using the above solvent system at a constant flow rate of $5 \mathrm{ml} / \mathrm{min}$. The detection wavelength was $254 \mathrm{~nm}$. In total, 42 fractions of varying volumes were collected based on absorbance values. The elution solvent of each fraction was evaporated and the residues were dissolved in $2 \mathrm{ml}$ of ethanol. Then, the solution was filtered through a $0.45 \mu \mathrm{m}$ filter and placed in HPLC vials for testing the presence of $\mathrm{Cu} \mathrm{D}$ and $\mathrm{Cu}$ I by HPLC-DAD. This procedure was repeated for each fraction. $\mathrm{Cu} \mathrm{D}$ and $\mathrm{Cu} \mathrm{I}$ identification was performed by comparing retention times and UV spectra of the compounds present in each fraction and the pure standards. The presence of $\mathrm{Cu} \mathrm{D}$ and $\mathrm{Cu}$ I (in varying amounts) was determined in eleven fractions. These fractions were pooled and concentrated by evaporation of ethanol. The remaining solution was about $5 \mathrm{ml}$, and it was placed in HPLC vials for further separation and purification.

A Nucleosil RP-C $\mathrm{C}_{18}$ column $(250 \mathrm{~mm} \times$ $4.6 \mathrm{~mm}$ id, $5 \mu \mathrm{m}$, pore size, $100 \AA$ ) was used for HPLC analysis. The chromatographic conditions were set by a slight modification of a previously described method [27, 32]. ACN/water (20:80, $\mathrm{v} / \mathrm{v})$ ) and $\mathrm{ACN} /$ water $(45: 55, \mathrm{v} / \mathrm{v})$ were used as mobile phases $\mathrm{A}$ and $\mathrm{B}$, respectively. The gradient elution started at $10 \%$ solvent $\mathrm{B}$, gradually increased to $100 \%$ solvent $\mathrm{B}$ in $60 \mathrm{~min}$, isocratic for $10 \mathrm{~min}$, then decreased to $10 \%$ solvent $\mathrm{B}$ in $5 \mathrm{~min}$ at a flow rate of $0.75 \mathrm{ml} / \mathrm{min}$ for a total period of $75 \mathrm{~min}$. After each test, the column was equilibrated for $5 \mathrm{~min}$.

HPLC analysis was carried out at constant column temperature $\left(40{ }^{\circ} \mathrm{C}\right)$, and a $10 \mu \mathrm{l}$ injection volume was taken for qualitative/quantitative analysis. Analyte absorbance was recorded in the range of $190-800 \mathrm{~nm}$ by using a DAD detector. Maximum $\mathrm{Cu} \mathrm{D}$ and $\mathrm{Cu} \mathrm{I}$ peak absorbances were at 230 and $235 \mathrm{~nm}$, respectively. Most cucurbitacins give $\mathrm{UV}$-absorbance at $229 \mathrm{~nm}$ because of their chemical structure [9]. Therefore, the cucurbitacins studied here were fractioned at $229 \mathrm{~nm}$.

For the purification step, the injection volume was increased to $50 \mu \mathrm{l}$ and the rest of the settings were kept as above. Fractions of $\mathrm{Cu} \mathrm{D}$ and $\mathrm{Cu}$ I were collected automatically by the fraction collector. The time based collection of the peaks was performed at about 36.50-38.50 minute intervals for $\mathrm{Cu} \mathrm{D}$ and $44.00-45.50 \mathrm{~min}$ interval for $\mathrm{Cu}$ 
I. $\mathrm{Cu} \mathrm{D}$ and $\mathrm{Cu}$ I fractions were pooled separately at room temperature and stored at $-18{ }^{\circ} \mathrm{C}$ for further processing. The collected fractions were divided into $5 \mathrm{ml}$ portions for lyophilization and kept at -18 ${ }^{\circ} \mathrm{C}$ overnight. The frozen samples were lyophilized to obtain solid purified $\mathrm{Cu} \mathrm{D}$ and $\mathrm{Cu}$ I crystals.

\subsection{Quantification and identification of the isolated cucurbitacins}

$\mathrm{Cu} \mathrm{D}$ and $\mathrm{Cu} \mathrm{I}$ standards were used for the quantification and identification of both cucurbitacin compounds. A stock solution of each standard was prepared in $5 \mathrm{ml}$ ethanol at a concentration of $1 \mathrm{mg} / \mathrm{ml}$ for $\mathrm{Cu} \mathrm{D}$ and $0.22 \mathrm{mg} / \mathrm{ml}$ for $\mathrm{Cu}$ I. Calibration standards were prepared at concentrations ranging from 10 to $500 \mu \mathrm{g} / \mathrm{ml}$ for $\mathrm{Cu} \mathrm{D}$ and from 5 to $100 \mu \mathrm{g} / \mathrm{ml}$ for $\mathrm{Cu}$ I. The calibration curves were separately drawn by plotting the peak area against the concentration of $\mathrm{Cu} \mathrm{D}$ and $\mathrm{Cu}$ I. The curves were analyzed using linear regression equations and correlation coefficients.

Quantification of individual cucurbitacins was directly determined by HPLC-DAD according to the above described HPLC method using external standard curves of the authentic standards. $\mathrm{Cu} D$ and $\mathrm{Cu}$ I concentrations were determined from the direct correlation between the peak area and amount.

The isolated compounds were further identified by spectroscopic methods including UV, LC$\mathrm{MS}$ and NMR. Isolated $\mathrm{Cu} \mathrm{D}$ and $\mathrm{Cu}$ I samples were dissolved in ethanol and determined by HPLC-DAD according to the method described above on the basis of retention time and by comparison of UV spectra of the standards. The mass spectrometer was operated in positive ionization mode for both $\mathrm{Cu} \mathrm{D}$ and $\mathrm{Cu}$ I with an ESI source and mass range set to $m / z \quad 100-1500$. The mobile phase ACN/water/methanol (33:34:33, v/v/v) with $0.1 \%$ formic acid $\left(\mathrm{CH}_{2} \mathrm{O}_{2}\right)$ was delivered at a constant flow rate of $0.8 \mathrm{ml} / \mathrm{min}$. ${ }^{1} \mathrm{H}$ NMR fingerprints were established to identify the $\mathrm{Cu} \mathrm{D}$ and $\mathrm{Cu} \mathrm{I}$ obtained by HPLC fractionation.

\subsection{Method validation}

The developed method was fully validated according to the International Conference on Harmonization guidelines (ICH Q2R1) [35]. Validation tests were performed for the limit of detection (LOD), limit of quantification (LOQ), linearity range, accuracy, precision (intra- and inter-day), ruggedness and stability.

The linearity of the method was determined at five different concentration levels (measure- ments were triplicated) for each cucurbitacin. The calibration curve for each cucurbitacin with the respective correlation coefficient was calculated by least-squares linear regression analysis of the peak area. The LOD and LOQ values were determined at signal-to-noise ratios of 3.3 and 10 , respectively. The precision of the method was demonstrated by inter-day (reproducibility) at four different days and intra-day (repeatability) at three times in a day operation under the same conditions, both expressed as variation studies and relative standard deviation (RSD \%). The accuracy of the method was determined by calculating the percent recovery of the compounds by the standard addition method. Known amounts of standard solutions of $\mathrm{Cu} \mathrm{D}$ and $\mathrm{Cu}$ I $(50,100$, and $150 \%)$ were added to prequantified sample solutions, and the quantity of each cucurbitacin was subsequently determined from the corresponding calibration curve. The accuracy was evaluated by calculating the mean recovery values which were calculated according to the following formula:

$$
\begin{gathered}
\text { Recovery }(\%)=((\text { detected amount-original } \\
\text { amount }) / \text { amount spiked }) \times 100
\end{gathered}
$$

The ruggedness of the method was determined by carrying out experiments on two different instruments (Shimadzu and Agilent HPLC, Agilent Technologies, Waldbronn, Germany) and by different operators using different columns (Nucleosil RP-C 18 column and Inertsil ODS $3 \mathrm{~V} \mathrm{C}_{18}, 4.6 \times$ $250 \mathrm{~mm}, 5 \mu \mathrm{m}$, GL Sciences Inc., Tokyo, Japan). In order to demonstrate the stability of the standard and sample solutions during analysis, the solutions were analyzed at times $0,24,48$ and $72 \mathrm{~h}$.

\section{RESULTS AND DISCUSSION}

Cucurbitacins exhibit a wide array of in vitro and in vivo pharmacological effects, including anti-tumor activity. Target compounds $(\mathrm{Cu} \mathrm{D}$ and I in present study) should be at high purity for studies such as cancer research. High purity isolated cucurbitacin compounds are being investigated for their anti-cancer activities in recent studies. For this purpose, we established a simple and reliable method for simultaneous isolation and purification of cucurbitacins starting from the fruit juice.

Extraction solvent type is the most important variable affecting extraction efficiency. The physical state of the starting material is also significant in terms of the progress of the extraction. This condition indirectly affects the amount of the target compound. According to the literature, the basic components of E. elaterium fruit juice are cucur- 
bitacin B, D, E and I [36]. A high ratio of $\mathrm{Cu} \mathrm{D}$ and I are obtained when the fruit juice is extracted directly with chloroform. This is an effective and selective solvent, and it was used for cucurbitacins for the first time. The extraction efficiency with chloroform was about $97 \%$ for both cucurbitacins. In contrast with methanol, the chloroform extract does not contain polar components; so there is no need for a further step to remove polar components. Since chloroform is highly volatile, the extraction was performed at room temperature. The FC separation yield was $91 \%$ for $\mathrm{Cu} \mathrm{D}$ and $90 \%$ for $\mathrm{Cu} \mathrm{I}$.

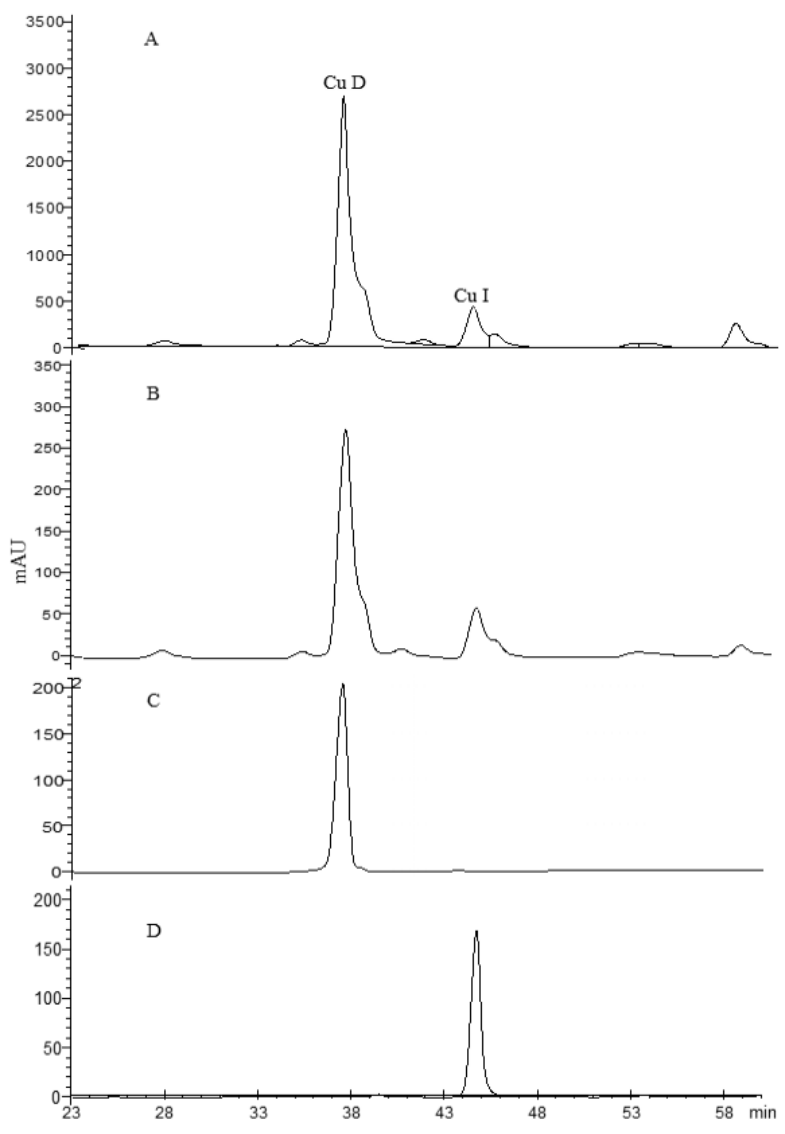

Fig. 2. HPLC chromatograms of (A) chloroform extract of E. elaterium fruit juice; (B) an $\mathrm{FC}$ fraction; (C) standard Cu D; (D) standard Cu I

The HPLC chromatograms of the chloroform extract of E. elaterium fruit juice, the FC fraction, and the authentic $\mathrm{Cu} \mathrm{D}$ and $\mathrm{Cu}$ I standards are given in Figure 2. The HPLC peaks of the chloroform extract and the $\mathrm{FC}$ fraction were similar, and the peaks of $\mathrm{Cu} \mathrm{D}$ and $\mathrm{Cu}$ I in these samples were in good agreement with those of the standards. $\mathrm{Cu} \mathrm{D}$ and $\mathrm{Cu}$ I were the major compounds in both the chloroform extract and the FC fractions. The peaks were sharp and symmetric. The intense peaks of $\mathrm{Cu} \mathrm{D}$ and $\mathrm{Cu}$ I in the chloroform extract indicated that $\mathrm{Cu} \mathrm{D}$ and $\mathrm{Cu}$ I were present in higher amounts than the other components. The retention times were $37.7 \pm 0.03 \mathrm{~min}$ for $\mathrm{Cu} \mathrm{D}$ standard and $44.7 \pm 0.04 \mathrm{~min}$ for $\mathrm{Cu}$ I standard.

The optimal analytical HPLC conditions such as the composition of the mobile phase, elution mode, flow rate, and column temperature were investigated by using a Nucleosil RP- $\mathrm{C}_{18}$ column $(250 \mathrm{~mm} \times 4.6 \mathrm{~mm}$ i.d., $5 \mu \mathrm{m})$.

Three mobile phase combinations tested for HPLC separation were (1) $100 \%$ ACN (phase A) $100 \%$ water (phase B), (2) $2 \%$ acetic acid in water (phase A) - $100 \%$ ACN (phase B) and (3) $0.1 \%$ TFA in water (phase A) - $100 \%$ ACN (phase B). The retention times of the components decreased and the resolution of the peaks increased in the presence of acetic acid and TFA phases. Although, this situation seems to be an advantage, the removal of the components from acetic acid and TFA phases at the final step requires an extra separation process. Therefore, ACN and water mixtures of different ratios were used as the mobile phase. The gradient elution program gave better peak shapes and resolution than the isocratic elution program. The retention time of $\mathrm{Cu} \mathrm{D}$ and $\mathrm{Cu}$ I decreased with increasing column temperature. Optimum separation and fractionation of $\mathrm{Cu} \mathrm{D}$ and $\mathrm{Cu}$ I was obtained at a $0.75 \mathrm{ml} / \mathrm{min}$ flow rate. HPLC injection volume was found to be an important factor affecting the separation efficiency. Good separation resolution was obtained with small injection volumes $(50 \mu \mathrm{l})$. Large injection volumes $(>50 \mu \mathrm{l})$ caused broadened peaks and poor separation of the target compounds.

$\mathrm{Cu} \mathrm{D}$ and $\mathrm{Cu}$ I peak fractions of the automatically collected samples were identified by comparing their retention times and UV spectra of HPLC-DAD with those of the standards. The retention times of the isolated $\mathrm{Cu} \mathrm{D}$ and $\mathrm{Cu}$ I were $37.6 \pm 0.03 \mathrm{~min}$ and $44.7 \pm 0.04 \mathrm{~min}$, respectively. The retention times of the isolated compounds were very close to the standard's retention times. The use of the DAD detector facilitated easy identification and determination of the purity of the compounds. The UV spectra of the standards and isolated $\mathrm{Cu} \mathrm{D}$ and $\mathrm{Cu}$ I are shown in Figure 3.

The peaks of the isolated $\mathrm{Cu} \mathrm{D}$ and $\mathrm{Cu} \mathrm{I}$ were in good agreement with those of the authentic standards. Peak purity index values were close to 1.0 for each cucurbitacin type. HPLC peak identification was determined by overlapping the chromatograms of the isolated $\mathrm{Cu} \mathrm{D}$ and $\mathrm{Cu}$ I with their standards as shown in Figure 4. Rapid and exact identification and determination of peaks in this way may be used to directly identify bioactive compounds in the mixtures. 

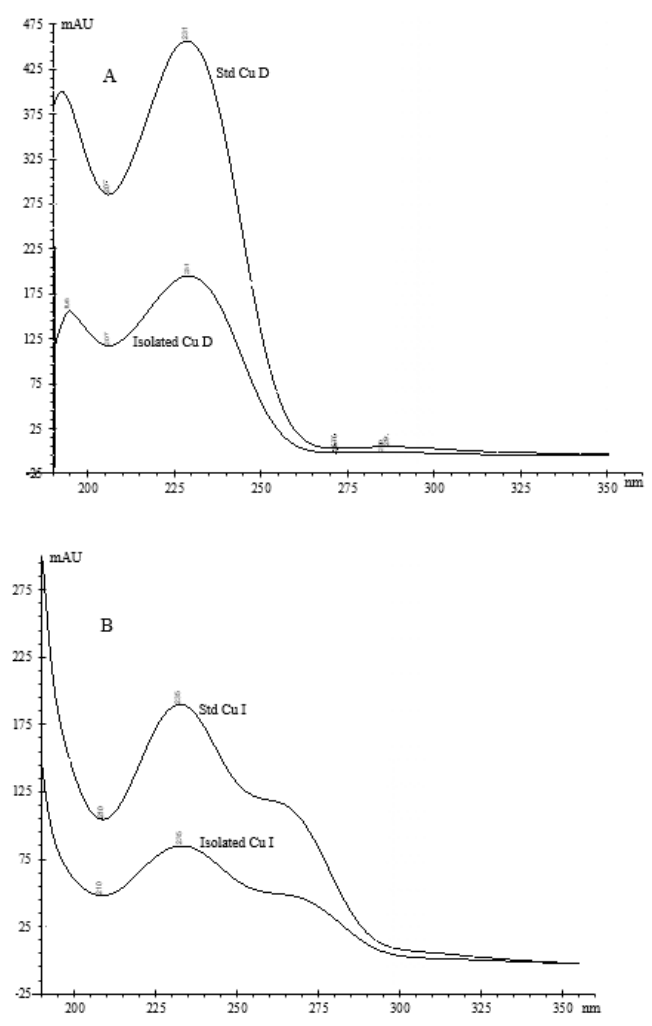

Fig. 3. Overlapping UV spectra of (A) standard and isolated $\mathrm{Cu}$ D; (B) standard and isolated $\mathrm{Cu}$ I

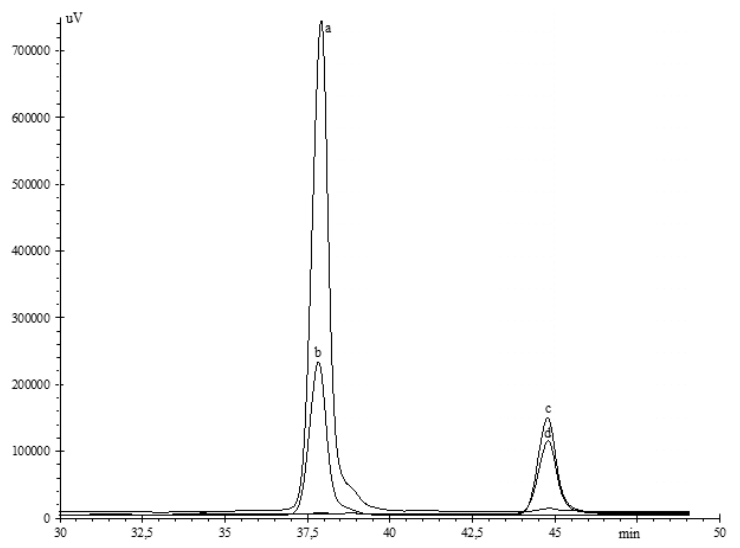

Fig. 4. Overlapping chromatograms of standard and isolated $\mathrm{Cu} \mathrm{D}$ and $\mathrm{Cu} \mathrm{I}$ (a: Standard Cu D; b: Isolated Cu D; c: Standard $\mathrm{Cu}$ I; d: Isolated Cu I)

LC-ESI-MS analysis was performed in positive ionization mode to obtain information on the composition of the standard $\mathrm{Cu} \mathrm{D}$ and $\mathrm{Cu} \mathrm{I}$ as well as isolated $\mathrm{Cu} \mathrm{D}$ and $\mathrm{Cu}$ I. The LC/MSD SL chromatograms are shown in Figure 5. The following interpretation of the major ion formation may be proposed: the characteristic protonated ion at $\mathrm{m} / \mathrm{z}$ $499.4\left[\mathrm{M}+\mathrm{H}-\mathrm{H}_{2} \mathrm{O}\right]^{+}$corresponds to $\mathrm{C}_{30} \mathrm{H}_{44} \mathrm{O}_{7}$ with molecular mass 516.7 for the isolated $\mathrm{Cu} \mathrm{D}$. The difference in the $\mathrm{m} / \mathrm{z}$ ratio was due to the facile loss of a molecule of water from $\mathrm{Cu} \mathrm{D}$ (Fig. 5(A)). This is also demonstrated with the mass chromatogram of the $\mathrm{Cu}$ D standard (Fig. 5(B)). The specific ion at $m / z 497.3\left[\mathrm{M}+\mathrm{H}-\mathrm{H}_{2} \mathrm{O}\right]^{+}$corresponds to the loss of a molecule of water from $\mathrm{C}_{30} \mathrm{H}_{42} \mathrm{O}_{7}$ with molecular mass 514.7 for the isolated Cu I (Fig. 5(C)) [3739]. The same mass chromatogram is observed for the $\mathrm{Cu}$ I standard (Fig. 5(D)).

Melting points of the isolated cucurbtacins were determined in open capillary tubes with a Branstead Electrothermal 9100 capillary melting point instrument and were uncorrected. The melting points of $151.2{ }^{\circ} \mathrm{C}$ and $149.3{ }^{\circ} \mathrm{C}$ were recorded for $\mathrm{Cu} \mathrm{D}$ and $\mathrm{Cu} \mathrm{I}$, respectively. These results were quite close and within the range of the values specified by the suppliers $[37,38]$.

Table 2

${ }^{1} \mathrm{H}-\mathrm{NMR}\left(600 \mathrm{MHz}, \mathrm{CHCl}_{3}\right)$ of cucurbitacins $D$ and $I$

\begin{tabular}{|c|c|c|}
\hline & Cucurbitacin D & Cucurbitacin I \\
\hline Position & $\delta \mathrm{H} / \mathbf{p p m}(\mathrm{J} / \mathrm{Hz})$ & $\delta_{\mathrm{H}} / \mathbf{p p m}(\mathrm{J} / \mathrm{Hz})$ \\
\hline $1 \alpha$ & $2.32 \mathrm{~m}$ & $2.96 \mathrm{~d}(2.7)$ \\
\hline $1 \beta$ & $1.22 \mathrm{~s}$ & - \\
\hline 2 & $4.39 \mathrm{~m}$ & - \\
\hline 3 & - & - \\
\hline 4 & - & - \\
\hline 5 & - & - \\
\hline 6 & 5.79 br d (6.0) & 5.89 br s \\
\hline $7 \alpha$ & $1.96 \mathrm{~m}$ & $2.36 \mathrm{~m}$ \\
\hline $7 \beta$ & $2.40 \mathrm{~d}(14.4)$ & $2.04 \mathrm{~m}$ \\
\hline 8 & 1.98 br d (7.8) & $2.03 \mathrm{~m}$ \\
\hline 9 & - & - \\
\hline 10 & 2.74 br d (12.6) & 3.49 br s \\
\hline 11 & - & - \\
\hline $12 \alpha$ & $3.25 \mathrm{~d}(15.0)$ & $3.23 \mathrm{~d}(14.4)$ \\
\hline $12 \beta$ & $\begin{array}{l}2.70 \mathrm{~d}(14.4) / 2.40 \mathrm{~d} \\
(14.4)\end{array}$ & $2.74 \mathrm{~d}(14.7)$ \\
\hline 13 & - & - \\
\hline 14 & - & - \\
\hline $15 \alpha$ & $1.39 \mathrm{dd}(1.8,7.2)$ & $1.64 \mathrm{~m}$ \\
\hline $15 \beta$ & $1.86 \mathrm{~d}(12.6)$ & $1.54 \ldots$ \\
\hline 16 & $4.08 \mathrm{~m}$ & $4.44 \mathrm{~m}$ \\
\hline 17 & $2.56 \mathrm{~d}(7.2)$ & $2.55 \mathrm{~d}(6.8)$ \\
\hline 18 & $0.99 \mathrm{~s}$ & $1.04 \mathrm{~s}$ \\
\hline 19 & $1.08 \mathrm{~s}$ & $0.88 \mathrm{~s}$ \\
\hline 20 & - & - \\
\hline 21 & $1.41 \mathrm{~s}$ & $1.39 \mathrm{~s}$ \\
\hline 22 & - & - \\
\hline 23 & $6.70 \mathrm{~d}(15.6)$ & $6.68 \mathrm{~d}(15.0)$ \\
\hline 24 & $7.12 \mathrm{~d}(15.2)$ & $7.09 \mathrm{~d}(15.0)$ \\
\hline 25 & - & - \\
\hline 26 & $1.35 \mathrm{~s}$ & $1.36 \mathrm{~s}$ \\
\hline 27 & $1.43 \mathrm{~s}$ & $1.28 \mathrm{~s}$ \\
\hline 28 & $1.25 \mathrm{~s}$ & $1.00 \mathrm{~s}$ \\
\hline 29 & $1.36 \mathrm{~s}$ & $0.87 \mathrm{~s}$ \\
\hline 30 & $1.28 \mathrm{~s}$ & $1.43 \mathrm{~s}$ \\
\hline
\end{tabular}



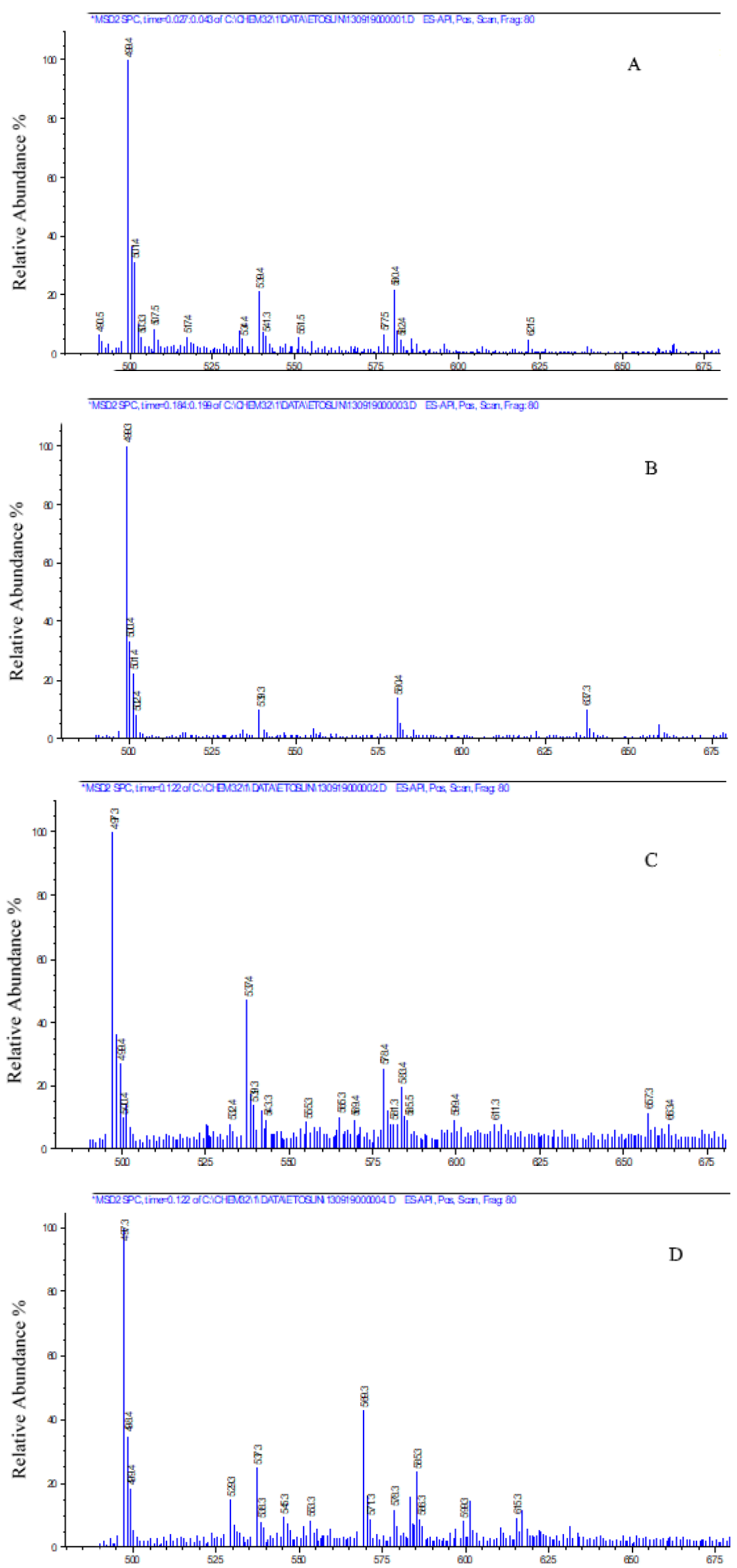

Fig. 5. The mass spectra of (A) isolated $\mathrm{Cu}$ D, (B) standard $\mathrm{Cu} \mathrm{D}$, (C) isolated Cu I, (D) standard Cu I 
The ${ }^{1} \mathrm{H}$ spectral data of the purified $\mathrm{Cu} \mathrm{D}$ and $\mathrm{Cu} \mathrm{I}$ are listed in Table 2. The ${ }^{1} \mathrm{H}$ NMR spectral data of $\mathrm{Cu}$ D (IUPAC Name: $(2 S, 8 S, 9 R, 10 R, 13 R, 14 S$, $16 R, 17 R)$-17-[(E,2R)-2,6-dihydroxy-6-methyl-3oxohept-4-en-2-yl]-2,16-dihydroxy-4, 4,9,13,14pentamethyl-2,7,8,10,12,15,16,17-octahydro- $1 H$ cyclopenta[a]phenanthrene-3,11-dione) (Fig. 6(A)) exhibited eight tertiary methyl group signals at $\delta_{\mathrm{H}}$ 0.99 (3H, s, H-18); 1.25 (3H, s, H-28); $1.36(3 \mathrm{H}, \mathrm{s}$, H-29); 1.28 (3H, s, H-30); 1.35 (3H, s, H-26); 1.43 $(3 \mathrm{H}, \mathrm{s}, \mathrm{H}-27) ; 1.41$ (3H, s, H-21); $1.08(3 \mathrm{H}, \mathrm{s}, \mathrm{H}-$ $19)$, an olefinic proton at $\delta_{\mathrm{H}} 5.79(1 \mathrm{H}$, br d, J $=6.0$ $\mathrm{Hz}, \mathrm{H}-6)$, two trans-coupled olefinic protons on a side chain at $\delta_{\mathrm{H}} 6.70(1 \mathrm{H}, \mathrm{d}, \mathrm{J}=15.6 \mathrm{~Hz}, \mathrm{H}-23)$ and $7.12(1 \mathrm{H}, \mathrm{d}, \mathrm{J}=15.2 \mathrm{~Hz}, \mathrm{H}-24)$, two hydroxymethine protons at $\delta_{\mathrm{H}} 4.39(1 \mathrm{H}, \mathrm{m}, \mathrm{H}-2)$ and $4.08(1 \mathrm{H}$, $\mathrm{m}, \mathrm{H}-16)$, and a pair of doublets at $\delta_{\mathrm{H}} 2.7,2.4(1 \mathrm{H}, \mathrm{d}$, $\mathrm{J}=14.4,14.4 \mathrm{~Hz}, \mathrm{H}-12 \beta)$ and $3.25(1 \mathrm{H}, \mathrm{d}, \mathrm{J}=15.0$ $\mathrm{Hz}, \mathrm{H}-12 \alpha$ ). The ${ }^{1} \mathrm{H}$ NMR spectral data of $\mathrm{Cu}$ I (IU-
PAC Name: $\quad(8 S, 9 R, 10 R, 13 R, 14 S, 16 R, 17 R)-17-$ [(E,2R)-2,6-dihydroxy-6-methyl-3-oxohept-4-en-2yl]-2,16-dihydroxy-4,4,9,13,14-pentamethyl-8,10, 12,15,16, 17-hexahydro-7H-cyclopenta[a]phenanthrene-3, 11-dione) (Fig. 6(B)) exhibited eight tertiary methyl group signals at $\delta_{\mathrm{H}} 1.04(3 \mathrm{H}, \mathrm{s}, \mathrm{H}-18)$; 1.00 (3H, s, H-28); 0.87 (3H, s, H-29); 1.43 (3H, s, H-30); 1.36 (3H, s, H-26); 1.28 (3H, s, H-27); 1.39 $(3 \mathrm{H}, \mathrm{s}, \mathrm{H}-21) ; 0.88(3 \mathrm{H}, \mathrm{s}, \mathrm{H}-19)$, an olefinic proton at $\delta_{\mathrm{H}} 5.79(1 \mathrm{H}$, br s, H-6), two trans-coupled olefinic protons on a side chain at $\delta_{\mathrm{H}} 6.68(1 \mathrm{H}, \mathrm{d}, \mathrm{J}$ $=15.0 \mathrm{~Hz}, \mathrm{H}-23)$ and $7.09(1 \mathrm{H}, \mathrm{d}, \mathrm{J}=15.0 \mathrm{~Hz}, \mathrm{H}-$ $24)$, a hydroxymethine protons at $\delta_{\mathrm{H}} 4.44(1 \mathrm{H}, \mathrm{m}$, $\mathrm{H}-16)$, and a pair of doublets at $\delta_{\mathrm{H}} 2.74(1 \mathrm{H}, \mathrm{d}, \mathrm{J}=$ 14.7, $14.4 \mathrm{~Hz}, \mathrm{H}-12 \beta)$ and $3.23(1 \mathrm{H}, \mathrm{d}, \mathrm{J}=14.4$ $\mathrm{Hz}, \mathrm{H}-12 \alpha) . \mathrm{Cu} \mathrm{D}$ and $\mathrm{Cu}$ I NMR signals were compared with the literature values and a good agreement was observed [40-45].

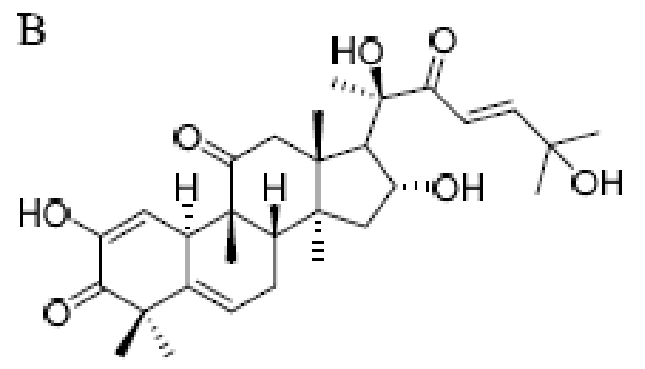

Fig. 6. The chemical structure of cucurbitacin D (A), cucurbitacin I (B)

The HPLC method was used to quantitatively determine the amount of $\mathrm{Cu} \mathrm{D}$ and $\mathrm{Cu}$ I isolated from the fruit juice. The lyophilized $\mathrm{Cu} \mathrm{D}$ and $\mathrm{Cu} \mathrm{I}$ crystals were dissolved in ethanol and the concentration of the compounds was calculated by individual calibration curves. The mean concentration values for three parallel determinations were $418 \pm 0.1$ $\mu \mathrm{M}$ for $\mathrm{Cu} \mathrm{D}$ and $296 \pm 0.1 \mu \mathrm{M}$ for $\mathrm{Cu}$ I. These values correspond to $86.4 \mu \mathrm{g} / \mathrm{g}$ dried residue for $\mathrm{Cu} \mathrm{D}$ and $61 \mu \mathrm{g} / \mathrm{g}$ dried residue for $\mathrm{Cu} \mathrm{I}$, respectively.

Linear calibration plots for $\mathrm{Cu} \mathrm{D}$ and $\mathrm{Cu} \mathrm{I}$ at five different concentrations were triplicated for method validation. The linear equations for calibration plots were $y=99480 x+279497\left(\mathrm{R}^{2}=\right.$ $0.9995)$ for $\mathrm{Cu} \mathrm{D}$ and $y=87193 x+31473\left(\mathrm{R}^{2}=\right.$ $0.9999)$ for $\mathrm{Cu}$ I. The LODs for $\mathrm{Cu} \mathrm{D}$ and $\mathrm{Cu} \mathrm{I}$ were $2.34 \mu \mathrm{g} / \mathrm{ml}$ and $1.79 \mu \mathrm{g} / \mathrm{ml}$, respectively. The LOQs for $\mathrm{Cu} \mathrm{D}$ and $\mathrm{Cu}$ I were $7.08 \mu \mathrm{g} / \mathrm{ml}$ and 5.98 $\mu \mathrm{g} / \mathrm{ml}$, respectively.

The recovery was $100.48,97.35$, and 100.45 for the known amount of 50,100, and $150 \% \mathrm{Cu} \mathrm{D}$, respectively, and $99.90,99.98$ and 101.27 for the known amount of 50, 100 and $150 \% \mathrm{Cu}$ I, respectively. The data showed that the added recoveries of the standards were accurate.

Intraday and inter-day RSDs were $0.25 \%$ and $1.58 \%$ for $\mathrm{Cu} \mathrm{D}$ and $0.21 \%$ and $1.65 \%$ for $\mathrm{Cu}$ I, respectively. Intraday RSDs were smaller than the inter-day RSDs for all tested samples. The HPLC method was found to be precise for intraday and inter-day RSD values. The relatively low RSDs for cucurbitacins in both intraday and interday experiments also indicated that the method was repeatable and reproducible. There were no marked changes in the chromatograms obtained from two different HPLC machines; thus, the developed HPLC method was rugged.

The standard and sample solutions were analyzed for stability at $0,24,48$, and $72 \mathrm{~h}$ after preparation. The peak areas of $\mathrm{Cu} \mathrm{D}$ and $\mathrm{Cu}$ I remained almost unchanged. Therefore, the standard and sample solutions were stable at least up to $72 \mathrm{~h}$. The results of linearity, LOD, LOQ, precision, and recovery are summarized in Table 3. 
An analytical HPLC purification method is much better than the other chromatographic methods to obtain high purity components. Subsequently, a simple, rapid and reliable HPLC method was developed for the simultaneous purification and quantification of the two cucurbitacins. The described HPLC method resulted in a good separation. The analytical method was also fully validated.

Several advantages of the developed method can be mentioned. First, the sample preparation is easy and only non-polar components like cucur- bitacins are extracted from fruit juice with chloroform. Second, the fractions which contain cucurbitacins are better separated using FC. Third, the HPLC conditions, in which aqueous acetonitrile is used as the mobile phase, are not complicated. This is also an advantage for removal of solvents from the final product without any impurities. Fourth, the high purity final product is suitable for medical research. Other benefits of the developed method include low cost analysis and good performance of analytical HPLC in contrast to expensive preparative HPLC.

Table 3

Summary of HPLC method validation for $C u D$ and $C u I$

\begin{tabular}{|c|c|c|}
\hline Parameters & Cu D & $\mathrm{Cu}$ I \\
\hline \multicolumn{3}{|l|}{ Linearity } \\
\hline Range $(\mu \mathrm{g} / \mathrm{ml})$ & $10-500$ & $4-100$ \\
\hline Linear equation & $y=99480 x+279497$ & $y=87193 x+31473$ \\
\hline Slope & 99480 & 87193 \\
\hline Intercept & 279497 & 31473 \\
\hline Correlation coefficient $\left(\mathrm{R}^{2}\right)$ & 0.9995 & 0.9999 \\
\hline \multicolumn{3}{|l|}{ Precision (RSD, \%) } \\
\hline Intraday & 0.25 & 0.21 \\
\hline Inter day & 1.58 & 1.65 \\
\hline $\mathrm{LOD}(\mu \mathrm{g} / \mathrm{ml})$ & 2.34 & 1.79 \\
\hline LOQ $(\mu \mathrm{g} / \mathrm{ml})$ & 7.08 & 5.98 \\
\hline \multicolumn{3}{|l|}{ Stability (RSD, \%) } \\
\hline $0 \mathrm{~h}$ & 0.44 & 0.98 \\
\hline $24 \mathrm{~h}$ & 0.43 & 1.19 \\
\hline $48 \mathrm{~h}$ & 0.40 & 0.53 \\
\hline $72 \mathrm{~h}$ & 0.48 & 1.07 \\
\hline \multicolumn{3}{|l|}{ Recovery (\%) } \\
\hline \multicolumn{3}{|l|}{ Level $1(50 \%)$} \\
\hline Original mean $(\mu \mathrm{g})$ & $32.47 \pm 0.61$ & $32.58 \pm 0.89$ \\
\hline Spiked mean $(\mu \mathrm{g})$ & 16.00 & 16.00 \\
\hline Detected mean $(\mu \mathrm{g})$ & $48.69 \pm 0.81$ & $48.53 \pm 0.89$ \\
\hline Recovery (\%) & 100.48 & 99.90 \\
\hline $\operatorname{RSD}(\%)$ & 1.67 & 1.87 \\
\hline \multicolumn{3}{|l|}{ Level $2(100 \%)$} \\
\hline Original mean $(\mu \mathrm{g})$ & $32.47 \pm 0.61$ & $32.58 \pm 0.89$ \\
\hline Spiked mean $(\mu \mathrm{g})$ & 32.00 & 32.00 \\
\hline Detected mean $(\mu \mathrm{g})$ & $62.76 \pm 0.53$ & $64.56 \pm 0.47$ \\
\hline Recovery (\%) & 97.35 & 99.98 \\
\hline RSD (\%) & 0.85 & 0.72 \\
\hline \multicolumn{3}{|l|}{ Level $3(150 \%)$} \\
\hline Original mean $(\mu \mathrm{g})$ & $32.47 \pm 0.61$ & $32.58 \pm 0.89$ \\
\hline Spiked mean $(\mu \mathrm{g})$ & 48.00 & 48.00 \\
\hline Detected mean $(\mu \mathrm{g})$ & $80.83 \pm 0.93$ & $81.60 \pm 0.99$ \\
\hline Recovery (\%) & 100.45 & 101.27 \\
\hline $\operatorname{RSD}(\%)$ & 1.15 & 1.21 \\
\hline
\end{tabular}




\section{CONCLUSIONS}

In the present study, a simple and effective procedure coupling FC and HPLC with a DAD detector has been developed for the separation, purification and quantification of $\mathrm{Cu} \mathrm{D}$ and $\mathrm{Cu} \mathrm{I}$ from a chloroform extract of E. elaterium fruit juice. The method was validated and quantified for $\mathrm{Cu} \mathrm{D}$ and $\mathrm{Cu}$ I. The method showed good linearity, accuracy and precision within acceptable limits, and the LOD and LOQ values confirmed the efficiency of the method at low concentrations of cucurbitacins. The purity of each isolated cucurbitacin was the same as its standard. The method developed here seems to be quite efficient for the separation and quantification of the components present in plant extracts.

Acknowledgement. The work was partially supported by Inonu University Scientific and Research Projects Unit (Project No: 2012/37).

\section{REFERENCES}

[1] E. Yesilada, S. Tanaka, E. Sezik, Isolation of an antiinflammatory principle from the fruit juice of Ecballium elaterium, J. Nat. Prod., 51(3), 504-508 (1988). https://pubs.acs.org/doi/abs/10.1021/np50057a008.

[2] E. G. Attard, A. Scicluna-Spiteri, Ecballium elaterium: an in vitro source of cucurbitacins, Fitoterapia, 72, 46-53 (2001). https://doi.org/10.1016/S0367-326X(00)00256-2.

[3] A. Ag1l, M. Miro, J. Jimenez, J. Anerios, M. D. Caracuel, A. Garciagranados, M. C. Navarro, Isolation of an anti-hepatotoxic principle from the juice of Ecballium elaterium. Planta. Med., 65, 673-675 (1999).

https://www.thieme-connect.de/DOI/DOI?10.1055/s2006-960847.

[4] H. G. Gerges, R. A. Khalil, E. A. Mansour, J. Magdalou, R. Chahine, N. Ouaini, Cucurbitacins from Ecballium elaterium juice increase the binding of bilirubin and ibuprofen to albumin in human plasma. Chem-Biol Interact., 169, 53-62 (2007).

https://doi.org/10.1016/j.cbi.2007.05.003.

[5] S. Bohlooli, N. Jafari, S. Jahed, Cytotoxic effect of freeze-dried extract of Ecballium elaterium fruit on gastric adenocarcinoma (AGS) and esophageal squamous cell carcinoma (KYSE30) cell lines. J Gastrointest Cancer, 43, 579-583 (2012).

https://link.springer.com/article/10.1007\%2Fs12029012-9383-4.

[6] A. S. Salhab, Human exposure to Ecballium elaterium fruit juice: fatal toxicity and possible remedy. Pharmacol Pharm, 4, 447-450 (2013). http://file.scirp.org/Html/6-2500327_36044.htm

[7] G. Toker, M. Memişoğlu, M. C. Toker, E. Yesilada, Callus formation and cucurbitacin B accumulation in Ecballium elaterium callus cultures. Fitoterapia, 74, 618-623 (2003).

https://doi.org/10.1016/S0367-326X(03)00165-5.
[8] I. Ielciu, M. Frederich, M. Tits, L. Angenot, R. Paltinean, E. Cieckiewicz, G. Crişan, L. Vlase, Bryonia alba L. and Ecballium elaterium (L) A Rich -Two related species of the cucurbitaceae family with important pharmaceutical potential. Farmacia, 64(3), 323-332 (2016). https://www.researchgate.net/publication/304990164.

[9] U. Kaushik, V. Aeri, S. R. Mir, Cucurbitacins - An insight into medicinal leads from nature. Pharmacogn. Rev., 9(17), 12-18 (2015).

https://www.ncbi.nlm.nih.gov/pmc/articles/PMC4441156/.

[10] J. Gry, I. Søborg, H. C. Andersson, Cucurbitacins in Plant Food Tema Nord Nordic Council of Ministers; Ekspressen Tryk \& Kopicenter; Copenhagen, 2006. https://www.diva-portal.org/smash/get/diva2:701868/ FULLTEXT01.pdf.

[11] M. Miro, Cucurbitacins and their pharmacological effects Phytother., 9, 159-168 (1995). https://doi.org/10.1002/ptr.2650090302.

[12] A. A. Alghasham, Cucurbitacins-a promising target for cancer therapy. Int. J. Health Sci., 7(1), 77-89 (2013). https://www.ncbi.nlm.nih.gov/pmc/articles/PMC3612419/.

[13] S. O. Chung, Y. J. Kim, S. U. Park, An updated review of cucurbitacins and their biological and pharmacological activities (Letter to the editor). EXCLI J, 14, 562-566 (2015). http://www.excli.de/vol14/Park_05052015_proof.pdf.

[14] I. T. Silva, F. C. Geller, L. Persich, S. E. Dudek, K. L. Lang, M. S. B. Caro, F. J. Duran, E. P. Schenkel, S. Ludwig, C. M. O. Simoes, Cytotoxic effects of natural and semisynthetic cucurbitacins on lung cancer cell line A549. Invest New Drug, 34(2), 139-148 (2016). https://link.springer.com/article/10.1007\%2Fs10637015-0317-4.

[15] D. H. Lee, G. B. Iwanski, N. H. Thoennissen, Cucurbitacin: ancient compound shedding new light on cancer treatment. Scientific World Journal, 10, 413-418 (2010).

https://www.hindawi.com/journals/tswj/2010/565972/abs/.

[16] L. H. Mary, Lakshmi, F. Tilton, J. Joseph, S. S. Solosan, D. Sudarsanam, Phytochemical antioxidant and cytotoxic properties of the fruit extract from Cucurbita digitate. Int J. Pharm. Pharm. Sci., 6(4), 353-356 (2014). https://innovareacademics.in/journal/ijpps/Vol6Issue4/9 124.pdf.

[17] K. Dhiman, A. Gupta, D. K. Sharma, N. S. Gill, A. Goyal, A review on the medicinally important plants of the family cucurbitaceae. Asian Journal of Clinical Nutrition, 4(1), 16-26 (2012).

https://scialert.net/abstract/?doi=ajcn.2012.16.26.

[18] N. S. Gill, M. Bali, Isolation of anti ulcer cucurbitane type triterpenoid from the seeds of Cucurbita pepo. Res J Phytochemistry, 5(2), 70-79, (2011). https://scialert.net/abstract/?doi=rjphyto.2011.70.79.

[19] L. Dinan, J. Harmatha, R. Lafont, Chromatographic procedure for the isolation of plant steroids. J. Chromatogr. A 935, 105-123 (2001). https://doi.org/10.1016/S0021-9673(01)00992-X.

[20] J. Bartalis, F. T. Halaweish, Relationship between Cucurbitacins reversed-phase high-performance liquid chromatography hydrophobicity index and basal cytotoxicity on HepG2 cells. J Chromatogr B, 818, 159-166 (2005). https://doi.org/10.1016/j.jchromb.2004.12.020. 
[21] W. A. Oleszek, Chromatographic determination of plant saponins. J. Chromatogr A, 967, 147-162 (2002). https://doi.org/10.1016/S0021-9673(01)01556-4.

[22] C. A. Rice, K. A Raymal, O. L. Chambliss, F. A. Johnson, Chromatographic and mass spectral analysis of $\mathrm{Cu}$ curbitacins of three Cucumis sativus cultivars, J. Agr Food Chem.,29, 194-196 (1981). https://pubs.acs.org/doi/abs/10.1021/jf00103a051.

[23] N. Hassan, J. Ahamad, S. Amin, M. Mujeeb, S. R. Mir, Rapid preparative isolation of erythrocentaurin from Enicostemma littorale by medium-pressure liquid chromatography its estimation by high-pressure thin-layer chromatography and its $\alpha$-amylase inhibitory activity, $J$. Sep. Sci., 38, 592-598 (2015). https://doi.org/10.1002/jssc.201401030.

[24] J. Tao, R. Yan, L. Zhao, D. Wang, X. Xu, Separation and purification of two taxanes and one xylosylcontaining taxane from Taxus wallichiana Zucc: A comparison between high-speed countercurrent chromatography and reversed-phase FC. J. Sep. Sci., 40(6), 1273-1282 (2017). https://doi.org/10.1002/jssc.201601066.

[25] S. Sturm, H. Stuppner, Analysis of cucurbitacins in medicinal plants by high pressure liquid chromatography-mass spectrometry, Phytochem Analysis, 11(2), 121-127 (2000). https://doi.org/10.1002/(SICI)10991565(200003/04)11:2<121:AID-PCA493>3.0.CO;2-9.

[26] G .I. Kaya and M. F. Melzig, Quantitative determination of cucurbitacin E and cucurbitacin I in homoeopathic mother tincture of Gratiola officinalis L by HPLC. Pharmazie, 63, 851-853 (2008). https://doi.org/10.1691/ph.2008.8197.

[27] F. T. Halaweish, D. W. Tallamy, Quantitative determination of cucurbitacins by high performance liquid chromatography and high performance thin layer chromatography, J. Liq. Chromatogr. 16, 497-511 (1993). https://doi.org/10.1080/10826079308020927.

[28] X. S. Feng, D. C. Wang, H. Cai, X. M. Deng, Y. R. Liu, Determination of the cucurbitacins from Cucubita pepo $\mathrm{cv}$ dayangua by HPLC, Zhong Yao Cai 30(4), 418-420 (2007). https://www.researchgate.net/publication/6164198_Dete rmination_of_the_cucurbitacins_from_Cucubita_pepo_ cv_dayangua_by_HPLC.

[29] S. Sasidharan, Y. Chen, D. Saravanan, K. M. Sundram, L. Y. Latha, Extraction isolation and characterization of bioactive compounds from plants' extracts. Afr. J. Tradit. Complem., 8(1), 1-10 (2011). https://www.ncbi.nlm.nih.gov/pmc/articles/PMC3218439/.

[30] P. B. Krepsky, M. O. Cervelin, D. Porath, R. R. Peters, R. Ribeiro-do-Valle, M. R. Farias, High performance liquid chromatography determination of cucurbitacins in the roots of Wilbrandia ebracteata Cogn. Braz. J. Pharmacog, 19(3), 715-719 (2009). http://dx.doi.org/10.1590/S0102-695X2009000500011.

[31] E. Sezik, Research on the Turkish medicinal plant, Chem. Nat. Compound, 33(5), 541-542 (1995). https://link.springer.com/article/10.1007/BF02254799.

[32] E. Attard, Rapid detection of Cucurbitacins in tissues and in vitro cultures of Ecballium elaterium (L.) A. Rich Cucurbit Genet. Coop Report, 25, 71-75 (2002). http://cuke.hort.ncsu.edu/cgc/cgc25/cgc25-25.pdf.
[33] C. C. Wang, L. G. Chen, T. L. Chang, C.T. Hsieh, Extracts of aquilaria hulls and use thereof in the treatment of cancer, US Patent 20110160152 A1, June 30, 2011. https://patents.google.com/patent/US20110160152A1/en.

[34] M. M. Saker, M. M. Farid, A. A. Fahmi, S. A. ElMekkawy, H. S. Taha, A. I. Amin, Large scale production of antitumor cucurbitacins from Ecballium elaterium using bioreactor, Afr. J. Biotechnol., 11(66), 12974-12982 (2012). http://dx.doi.org/10.5897/AJB12.878.

[35] ICH Q2 (R1). Proceedings of International Conference of Harmonization. Geneva, 2005.

http://www.ema.europa.eu/docs/en_GB/document_librar y/Scientific_guideline/2009/09/WC500002662.pdf.

[36] S. Hu, Y. Wang, B. Avula, M. Wang, I. A. Khan, Separation of cucurbitane triterpenoids from bitter melon drinks and determination of partition coefficients using vortexassisted dispersive liquid-phase microextraction followed by UHPLC analysis, J. Sep. Sci, 40, 2238-2245 (2017). https://doi.org/10.1002/jssc.201700023.

[37] Cucurbitacin D. https://pubchem.ncbi.nlm.nih.gov/compound/Cucurbitac in-D, accessed September 2019.

[38] Cucurbitacin I. https://pubchem.ncbi.nlm.nih.gov/compound/Cucurbitac in-I, accessed September 2019.

[39] V. Subbiah, Method of isolating cucurbitacin. US Patent 5925356, July 20, 1999. https://patents.google.com/patent/US5925356A/en.

[40] C. Che, X. Fang, C. H. Phobe, A. D. Kinghorn, N. R. Farnsworth, High-field ${ }^{1} \mathrm{H}-\mathrm{NMR}$ analysis of some cucurbitacins, J. Nat. Prod., 48(3), 429-434 (1985). https://pubs.acs.org/doi/abs/10.1021/np50039a010.

[41] C. Seger, S. Sturm, M. E. Mair, E. P. Ellmerer, H. Stuppner, ${ }^{1} \mathrm{H}$ and ${ }^{13} \mathrm{C}$ NMR signal assignment of cucurbitacin derivates from Citrillus colocynthis (L) Schrader and Ecballium elaterium L (Cucurbitaceae). Magn. Reson. Chem., 43, 489-491 (2005). https://doi.org/10.1002/mrc.1570.

[42] C. Seger, S. Sturm, E. Haslinger, H. Stuppner, NMR signal assignment of 22-deoxocucurbitacin D and cucurbitacin D from Ecballium elaterium L (Cucurbitaceae). Monatshefte für Chemie, 136, 1645-1649 (2005). https://link.springer.com/article/10.1007/s00706-0050347-2.

[43] M. Wen-Li, L. Feng, Z. Wen-Jian, W. Hui, D. Hao-Fu, Cucurbitacins from fruits of Aquilaria sinensis. Chin. J. Nat. Med., 10(3), 234-237 (2012). https://doi.org/10.3724/SP.J.1009.2012.00234.

[44] A. Alsayari, L. Kopel, M. S. Ahmed, H. S. M. Soliman, S. Annadurai, F.T. Halaweish, Isolation of anticancer constituents from Cucumis propheratum var. propheratum through bioassay-guided fractionation. BMC Complem. Altern M, 18, 1-12 (2018). https://doi.org/10.1186/s12906-018-2295-5.

[45] R. Chawech, R. Jarraya, C. Girardi, M. Vansteelandt, G. Marti, I. Nasri, C. Racaud-Sultan, N. Fabre, Cucurbitacins from the leaves of Citrullus colocynthis (L.) Schrad, Molecules, 20, 18001-18015 (2015). DOI:10.3390/molecules20101800 